\title{
Age, Growth, and Mortality of Introduced Flathead Catfish in Atlantic Rivers and a Review of Other Populations
}

\author{
Thomas J. KwaK,* William E. Pine III, ${ }^{1}$ and D. Scott Waters ${ }^{2}$ \\ U.S. Geological Survey, North Carolina Cooperative Fish and Wildlife Research Unit, ${ }^{3}$ North Carolina State \\ University, Campus Box 7617, Raleigh, North Carolina 27695, USA
}

\begin{abstract}
Knowledge of individual growth and mortality rates of an introduced fish population is required to determine the success and degree of establishment as well as to predict the fish's impact on native fauna. The age and growth of flathead catfish Pylodictis olivaris have been studied extensively in the species' native and introduced ranges, and estimates have varied widely. We quantified individual growth rates and age structure of three introduced flathead catfish populations in North Carolina's Atlantic slope rivers using sagittal otoliths, determined trends in growth rates over time, compared these estimates among rivers in native and introduced ranges, and determined total mortality rates for each population. Growth was significantly faster in the Northeast Cape Fear River (NECFR) than in the Lumber and Neuse rivers. Fish in the NECFR grew to a total length of $700 \mathrm{~mm}$ by age 7, whereas fish in the Neuse and Lumber river populations reached this length by 8 and 10 years, respectively. The growth rates of fish in all three rivers were consistently higher than those of native riverine populations, similar to those of native reservoir populations, and slower than those of other introduced riverine populations. In general, recent cohorts (1998-2001 year-classes) in these three rivers exhibited slower growth among all ages than did cohorts previous to the 1998 year-class. The annual total mortality rate was similar among the three rivers, ranging from 0.16 to 0.20 . These mortality estimates are considerably lower than those from the Missouri and Mississippi rivers, suggesting relatively low fishing mortality for these introduced populations. Overall, flathead catfish populations in reservoirs grow faster than those in rivers, the growth rates of introduced populations exceed those of native populations, and eastern United States populations grow faster than those in western states. Such trends constitute critical information for understanding and managing local populations.
\end{abstract}

Quantification of age and growth is a vital component for understanding the ecology and life history of any fish species. This is especially important for an introduced species like flathead catfish Pylodictis olivaris in the Atlantic slope and elsewhere in the United States. Knowledge of the individual growth rates and age structure of an introduced population is required to determine the success and degree of establishment as well as to predict the fish's impact on native fauna. Growth rate information can also be used to compare dynamics among water bodies, years, and fish sizes; describe trends over time; examine total mortality rates; and determine the general status of a population.

Flathead catfish age and growth have been studied

\footnotetext{
* Corresponding author: tkwak@ncsu.edu

${ }^{1}$ Present address: Department of Fisheries and Aquatic Sciences, University of Florida, 7922 Northwest 71st Street, Gainesville, Florida 32653, USA.

${ }^{2}$ Present address: Kansas Department of Wildlife and Parks, Glen Elder Area Office, 2131180 Road, Glen Elder, Kansas 67446, USA.

${ }^{3}$ The Unit is jointly supported by North Carolina State University, North Carolina Wildlife Resources Commission, U.S. Geological Survey, and Wildlife Management Institute.
}

Received August 19, 2004; accepted September 27, 2005 Published online January 5, 2006 sufficiently to allow elucidation of trends among geographic regions, aquatic habitats (rivers and reservoirs), and native and introduced populations (Tables $1-3)$. In native riverine populations of flathead catfish, the maximum reported age ranged from 5 years in the Neosho River, Kansas (Minckley and Deacon 1959), to 28 years in the Tallapoosa River, Alabama (Nash 1999). Growth to quality size (510 mm; Quinn 1991) may be obtained between 3 years (Francis 1993) and 9 years (Nash 1999). Memorable-size flathead catfish (860 mm; Quinn 1991) range in age from 8 years (Cross and Hastings 1956; Francis 1993) to 22 years (Nash 1999); however, most populations yield fish of that size by age 12 . Fish over age 13 or $1,000 \mathrm{~mm}$ are rare to nonexistent in most populations; the maximum reported length was $1,118 \mathrm{~mm}$ from a fish captured in the Kansas River, Kansas (Cross and Hastings 1956). The Tallapoosa River population studied by Nash (1999) was perceived to grow considerably slower and live longer than any other native population.

Most investigators have used pectoral spines to age flathead catfish, and the results may be variably biased, especially for older fish. Nash and Irwin (1999) compared otoliths and pectoral spines for use in aging flathead catfish and determined that otoliths yielded more accurate age estimates due to annuli being more 
TABLE 1.-Average back-calculated total length at age for native flathead catfish from selected riverine populations.

\begin{tabular}{|c|c|c|c|c|c|c|c|c|c|c|c|c|c|c|}
\hline \multirow[b]{2}{*}{ Location and statistic } & \multicolumn{14}{|c|}{ Total length $(\mathrm{mm})$ at age } \\
\hline & 1 & 2 & 3 & 4 & 5 & 6 & 7 & 8 & 9 & 10 & 11 & 12 & 13 & 14 \\
\hline Tennessee River, Alabama & 93 & 157 & 199 & 239 & 318 & 384 & 367 & 451 & 387 & & & & & \\
\hline Black Warrior River, Alabama & 122 & 211 & 271 & 392 & 474 & 503 & 697 & & 879 & & & & & \\
\hline Coosa River, Alabama & 109 & 168 & 204 & 391 & 492 & 517 & 610 & 545 & 571 & 684 & & & & \\
\hline Alabama River, Alabama & 110 & 189 & 265 & 433 & 534 & 544 & 560 & & 785 & & & & & \\
\hline Tallapoosa River, Alabama & 147 & 208 & 261 & 307 & 351 & 398 & 427 & 484 & 510 & 513 & 535 & 540 & 565 & 589 \\
\hline Missouri River, Missouri & 119 & 188 & 251 & 310 & 368 & 419 & 490 & 526 & 597 & 645 & 673 & 688 & & \\
\hline Minnesota River, Minnesota & 96 & 195 & 319 & 436 & 520 & 584 & 649 & 703 & 752 & 798 & 932 & 875 & 924 & 947 \\
\hline Big Black River, Mississippi & 199 & 299 & 407 & 498 & 590 & 666 & 801 & 869 & 1,040 & 1,085 & & & & \\
\hline Tallahatchie River, Mississippi & 214 & 326 & 479 & 575 & 671 & 806 & 939 & 1,001 & 1,059 & & & & & \\
\hline Rio Grande River, Texas & 61 & 124 & 232 & 350 & 485 & 590 & 673 & 757 & 914 & & & & & \\
\hline Missouri River, Nebraska & 75 & 188 & 321 & 411 & 487 & 541 & 536 & & & & & & & \\
\hline Des Moines River, Iowa & 142 & 269 & 393 & 469 & 550 & 600 & 674 & 714 & & & & & & \\
\hline Big Blue River, Kansas & 142 & 262 & 366 & 483 & 630 & & 701 & 772 & & & & & & \\
\hline Neosho River, Kansas & 96 & 227 & 319 & 390 & 438 & & & & & & & & & \\
\hline Salt River, Missouri & 76 & 155 & 231 & 300 & 348 & 422 & 452 & 503 & 599 & & & & & \\
\hline Verdigris River, Oklahoma & 91 & 155 & 206 & 274 & 320 & 373 & 419 & 523 & 584 & 615 & & & & \\
\hline Kansas River, Kansas & 210 & 254 & 400 & 622 & 648 & 819 & 851 & 1,022 & 1,118 & 889 & & & & \\
\hline $\begin{array}{l}\text { Mississippi River, } \\
\text { Illinois-Missouri }^{\mathrm{a}}\end{array}$ & 191 & 304 & 406 & 457 & 482 & 559 & 660 & 787 & 851 & & & 914 & & \\
\hline $\begin{array}{l}\text { Mississippi River, } \\
\text { Iowa-Illinois }^{\mathrm{a}}\end{array}$ & 165 & 267 & 305 & 394 & 432 & 508 & 596 & 635 & 699 & 826 & 864 & & 902 & 953 \\
\hline Mean & 129.4 & 218.2 & 307.1 & 406.9 & 481.0 & 543.1 & 616.8 & 677.1 & 756.3 & 747.0 & 713.4 & 754.4 & 744.5 & 768.0 \\
\hline SE & 10.9 & 13.3 & 18.8 & 22.8 & 24.9 & 31.9 & 36.4 & 45.4 & 56.3 & 63.9 & 90.5 & 86.8 & 116.2 & 120.3 \\
\hline
\end{tabular}

${ }^{\mathrm{a}}$ Data estimated from figure.

distinguishable, especially for older fish (i.e., over age 5). Pectoral spines consistently underestimated ages of older fish due to the erosion of the central lumen, which led to loss of annuli. Only several recent studies have estimated ages of flathead catfish with otoliths (e.g., Mayo and Schramm 1999; Nash 1999; Grabowski et al. 2004). Pectoral spines were used by all others (Tables 1-3) except for Pate (1980), who examined vertebrae. Thus, caution regarding the accuracy of reported ages should be exercised when interpreting results among studies, but examination of trends for young fish may be suitable for comparisons among populations.

Flathead catfish mortality has rarely been studied in the species' native range, and we found no total mortality rates reported for populations in the fish's introduced range. The only published mortality rate estimated for an introduced population was that by Quinn (1993), who estimated annual fishing mortality for Flint River, Georgia, flathead catfish to be 14-25\%. Summerfelt et al. (1972) used the Robson-Chapman estimator in Lake Carl Blackwell, Oklahoma, and reported annual total mortality rates of $31-49 \%$. Robinson (1997) estimated annual total mortality rates over several years from catch curves in the Missouri and Mississippi rivers. Annual total mortality averaged $56 \%$ (range $=51-67 \%$ ) in the Missouri River near Easly, Missouri, and $49 \%$ (range $=43-54 \%$ ) in the Mississippi River at Crystal City, Missouri. Flathead catfish population modeling by Robinson (1997) suggested that a reduction of total mortality to $40 \%$ would increase the numbers of large fish and improve

TABLE 2.-Average back-calculated total length at age for native flathead catfish from selected reservoir populations.

\begin{tabular}{|c|c|c|c|c|c|c|c|c|c|c|}
\hline \multirow[b]{2}{*}{ Location and statistic } & \multicolumn{10}{|c|}{ Total length $(\mathrm{mm})$ at age } \\
\hline & 1 & 2 & 3 & 4 & 5 & 6 & 7 & 8 & 9 & 10 \\
\hline Lake Carl Blackwell, Oklahoma & 58 & 117 & 198 & 309 & 446 & 549 & 623 & 678 & 714 & 738 \\
\hline Milford Reservoir, Kansas & 164 & 230 & 316 & 412 & 517 & 591 & 700 & 796 & 837 & 869 \\
\hline Bluestone Reservoir, West Virginia & 216 & 351 & 478 & 571 & 626 & 680 & 730 & 744 & 762 & 786 \\
\hline Watts Bar Reservoir, Tennessee & 239 & 353 & 475 & 579 & 643 & 780 & 907 & 985 & 1,021 & 1,074 \\
\hline Norris Reservoir, Tennessee & 132 & 239 & 351 & 472 & 589 & 671 & 737 & 790 & 841 & 879 \\
\hline Grand Lake, Oklahoma (Neosho Arm) & 140 & 259 & 381 & 490 & 584 & 655 & 719 & 785 & 879 & 945 \\
\hline Grand Lake, Oklahoma (main body) & 86 & 160 & 241 & 323 & 384 & 439 & 485 & 518 & & \\
\hline Boomer Lake, Oklahoma & & 287 & 460 & 638 & 742 & 826 & 884 & 927 & 968 & 1,003 \\
\hline Mean & 147.9 & 249.5 & 362.5 & 474.2 & 566.3 & 648.8 & 723.1 & 777.9 & 860.2 & 899.2 \\
\hline SE & 24.6 & 29.5 & 37.8 & 42.5 & 40.3 & 43.8 & 47.7 & 50.8 & 40.7 & 44.6 \\
\hline
\end{tabular}


TABLE 1.-Extended.

\begin{tabular}{|c|c|c|c|c|c|c|c|c|c|c|c|c|c|c|c|}
\hline \multirow[b]{2}{*}{ Location and statistic } & \multicolumn{14}{|c|}{ Total length $(\mathrm{mm})$ at age } & \multirow[b]{2}{*}{ Reference } \\
\hline & 15 & 16 & 17 & 18 & 19 & 20 & 21 & 22 & 23 & 24 & 25 & 26 & 27 & 28 & \\
\hline Tennessee River, Alabama & & & & & & & & & & & & & & & Grussing et al. (2000) \\
\hline Black Warrior River, Alabama & & & & & & & & & & & & & & & Grussing et al. (2000) \\
\hline Coosa River, Alabama & & & & & & & & & & & & & & & Grussing et al. (2000) \\
\hline Alabama River, Alabama & & & & & & & & & & & & & & & Grussing et al. (2000) \\
\hline Tallapoosa River, Alabama & 589 & 598 & 619 & 650 & 673 & 764 & 858 & 880 & 900 & 922 & 947 & 953 & 968 & 990 & Nash (1999) \\
\hline Missouri River, Missouri & & & & & & & & & & & & & & & Robinson et al. (1997) \\
\hline Minnesota River, Minnesota & 970 & 1,016 & 1,045 & 1,060 & 1,054 & & & & & & & & & & Stauffer et al. (1996) \\
\hline Big Black River, Mississippi & & & & & & & & & & & & & & & Francis (1993) \\
\hline Tallahatchie River, Mississippi & & & & & & & & & & & & & & & Francis (1993) \\
\hline Rio Grande River, Texas & & & & & & & & & & & & & & & Pate (1980) \\
\hline Missouri River, Nebraska & & & & & & & & & & & & & & & Holz (1969) \\
\hline Des Moines River, Iowa & & & & & & & & & & & & & & & Mayhew (1969) \\
\hline Big Blue River, Kansas & & & & & & & & & & & & & & & Minckley and Deacon (1959) \\
\hline Neosho River, Kansas & & & & & & & & & & & & & & & Minckley and Deacon (1959) \\
\hline Salt River, Missouri & & & & & & & & & & & & & & & Purkett (1958) \\
\hline Verdigris River, Oklahoma & & & & & & & & & & & & & & & Jenkins and Finnell (1957) \\
\hline Kansas River, Kansas & & & & & & & & & & & & & & & Cross and Hastings (1956) \\
\hline Mississippi River, & 1 & & & & & & & & & & & & & & Barnickol and Starrett (1951) \\
\hline Mississippi River, & 1,041 & & & & & & & & & & & & & & Barnickol and Starrett (1951) \\
\hline Iowa-Illinois $^{\mathrm{a}}$ & 953 & & & & & & & & & & & & & & \\
\hline Mean & 780 & 807 & 832 & 855 & 864 & 764 & 858 & 880 & 900 & 922 & 947 & 953 & 968 & 990 & \\
\hline SE & 269 & 296 & 301 & 290 & 269 & & & & & & & & & & \\
\hline
\end{tabular}

population size structure. Winkelman (2002) examined the effects of hand grappling (noodling) for the flathead catfish populations in Lakes Carl Blackwell and McMurty, Oklahoma, and reported annual total mortality rates of $17 \%$ and $16 \%$, respectively.

The objectives of our research were to (1) quantify individual growth rates and age structure of introduced flathead catfish populations in three Atlantic coastal plain rivers of North Carolina, (2) determine trends in growth rate over time, (3) determine total mortality rates for each population, (4) compare growth and mortality estimates among rivers, and (5) compare our findings with those from rivers and reservoirs in both the native and introduced ranges to elucidate trends among populations. Based on a nonexhaustive literature review, we predicted that flathead catfish growth rates in North Carolina coastal plain rivers would be high compared to those of native populations and similar to other introduced populations in the southeastern USA.

\section{Methods}

North Carolina Atlantic rivers.-We selected three North Carolina Atlantic coastal plain river systems for study. Flathead catfish have been introduced into each watershed. The Northeast Cape Fear River (NECFR) supports the oldest population (about 30 years), the Neuse River supports a more recent population (about 20 years), and the Lumber River is the site of the most recent ( $<10$ years) introduction (Kwak et al. 2004). The Neuse River is formed by the confluence of the Flat and Eno rivers; it varies widely in depth and width

TABLE 2.-Extended.

\begin{tabular}{|c|c|c|c|c|c|c|c|c|c|c|}
\hline \multirow[b]{2}{*}{ Location and statistic } & \multicolumn{9}{|c|}{ Total length $(\mathrm{mm})$ at age } & \multirow[b]{2}{*}{ Reference } \\
\hline & 11 & 12 & 13 & 14 & 15 & 16 & 17 & 18 & 19 & \\
\hline Lake Carl Blackwell, Oklahoma & 761 & 785 & 794 & & & & & & & Turner (1982) \\
\hline Milford Reservoir, Kansas & 894 & 909 & 926 & 942 & 915 & 925 & & & & Layher and Boles (1979) \\
\hline Bluestone Reservoir, West Virginia & 798 & 751 & 675 & 682 & & & & & & Edmundson (1974) \\
\hline Watts Bar Reservoir, Tennessee & 1,100 & & & & & & & & & Hargis (1966) \\
\hline Norris Reservoir, Tennessee & 947 & 991 & 1,008 & 1,013 & 1,036 & 1,067 & & & & Carroll and Hall (1964) \\
\hline Grand Lake, Oklahoma (Neosho Arm) & 1,013 & 1,074 & & & & & & & & McCoy (1953) \\
\hline Grand Lake, Oklahoma (main body) & & & & & & & & & & McCoy (1953) \\
\hline Boomer Lake, Oklahoma & 1,031 & 1,072 & 1,090 & 1,092 & 1,102 & 1,074 & 1,072 & 1,085 & 1,067 & McCoy (1953) \\
\hline Mean & 934.9 & 930.3 & 898.5 & 932.3 & $1,017.8$ & $1,022.1$ & $1,071.9$ & $1,084.6$ & $1,066.8$ & \\
\hline $\mathrm{SE}$ & 47.2 & 57.2 & 74.2 & 88.9 & 54.8 & 48.6 & & & & \\
\hline
\end{tabular}


TABLE 3.-Average back-calculated total length at age for introduced flathead catfish from selected riverine populations.

\begin{tabular}{|c|c|c|c|c|c|c|c|c|c|}
\hline \multirow[b]{2}{*}{ Location and statistic } & \multicolumn{9}{|c|}{ Total length $(\mathrm{mm})$ at age } \\
\hline & 1 & 2 & 3 & 4 & 5 & 6 & 7 & 8 & 9 \\
\hline Neuse River, North Carolina & 191 & 306 & 407 & 490 & 566 & 623 & 676 & 710 & 741 \\
\hline Northeast Cape Fear River, North Carolina & 154 & 257 & 351 & 498 & 599 & 654 & 701 & 757 & 790 \\
\hline Lumber River, North Carolina & 160 & 258 & 345 & 436 & 507 & 586 & 627 & 643 & 675 \\
\hline Altamaha River, Georgia ${ }^{a}$ & 154 & 265 & 370 & 478 & 568 & 612 & 664 & 680 & 713 \\
\hline Ocmulgee River, Georgia & 270 & 398 & 509 & 605 & 691 & 759 & 821 & 889 & 947 \\
\hline Edisto River, South Carolina & 260 & 360 & 550 & 769 & 970 & 1,153 & 1,067 & 1,030 & \\
\hline $\begin{array}{l}\text { Little River and Long Cane, } \\
\text { South Carolina }\end{array}$ & & 510 & 731 & 789 & 883 & 864 & 1,018 & 1,004 & 961 \\
\hline Great Pee Dee River, South Carolina & 255 & 419 & 539 & 560 & 642 & 671 & 761 & 712 & 832 \\
\hline Flint River, Georgia & 203 & 352 & 497 & 613 & 710 & 774 & 833 & 935 & 1,000 \\
\hline Cape Fear River, North Carolina & 155 & 311 & 479 & 580 & 640 & 711 & 812 & 907 & \\
\hline Colorado River, Arizona-California & 106 & 195 & 382 & 455 & 586 & 710 & 798 & & \\
\hline Verde River, Arizona & 118 & 223 & 362 & 470 & 621 & 747 & 785 & & \\
\hline Coachella Canal, California & 123 & 240 & 382 & 487 & 578 & 665 & 732 & 800 & \\
\hline Mean & 181.4 & 319.2 & 461.2 & 562.7 & 666.1 & 743.1 & 802.6 & 838.7 & 849.4 \\
\hline SE & 17.9 & 26.7 & 32.7 & 33.7 & 38.8 & 43.0 & 37.1 & 42.1 & 46.5 \\
\hline
\end{tabular}

${ }^{\text {a }}$ Fish lengths reported as fork length $(\mathrm{mm})$; data not included in means, SE, or Figure 4.

along 443 river kilometers (rkm) before flowing into Pamlico Sound. The NECFR, located in the Cape Fear River drainage, is a relatively deep river (average depth $=3.0 \mathrm{~m}$ ), possesses some tidal influence, and has an average width of $45 \mathrm{~m}$. It rises in Wayne County and flows southeast for $209 \mathrm{rkm}$ to the Cape Fear River at Wilmington. The Lumber River is a blackwater river with an average width of $37 \mathrm{~m}$ and an average depth of $0.9 \mathrm{~m}$. It is located in the Pee Dee River watershed and flows $201 \mathrm{rkm}$ from south-central North Carolina to the Little Pee Dee River near Nichols, South Carolina.

Fish collection and age estimation.-We collected flathead catfish $(N=114)$ from the Neuse River near Kinston during September-October 2001 and from the river near Raleigh during April-May 2003. We also collected fish $(N=94)$ from the NECFR downstream of Burgaw during August-September 2002 and May 2003 and from the Lumber River $(N=36)$ near Fairmont at Lumber River State Park in May 2003. We used a boat-mounted, low-frequency, pulsed DC electrofisher to capture flathead catfish at all sites and returned them to the laboratory for processing. All fish were sacrificed by submersion in an ice bath or an overdose in a clove oil solution.

We measured total length $( \pm 1 \mathrm{~mm})$ and weight $( \pm 1$ $\mathrm{g}$ ), sexed each fish if possible by direct observation of the gonads, and assigned an identification number to each fish. Sagittal otoliths were removed from all flathead catfish by sectioning the supraoccipital bone with a fillet knife, hacksaw, or circular saw depending on fish size, and otoliths were stored in coin envelopes. Otoliths were prepared similarly to the methods of Maceina (1988) and Nash (1999), except with a few modifications. Otoliths were removed from envelopes, cleaned as necessary, and placed directly on a hot plate for approximately $5 \mathrm{~min}$. Crystalbond was melted onto a microscope slide in a dime-size pile, and the otolith was inserted anterior side up. The otoliths were polished with 600-grit sandpaper and were viewed under a compound microscope (100×; Figure 1). A subsample of otoliths was read independently by two readers who were naive of the fish's total length or weight; the remainder was read by a single reader. Any discrepancies in age estimation were reconciled with a concert read.

Back-calculation.-Back-calculation of length at age was completed by use of the Fraser-Lee direct proportion method (Carlander 1982). When available, five fish were randomly selected from each age-class within each river. We measured otolith radius by use of Image Pro Analysis Software (Media Cybernetics 2002). The total radius was equal to the distance between the center of the nucleus and the edge of the otolith. Annual growth was measured from the anterior edge of one annulus to the anterior edge of the adjacent annulus. Fish collected during fall were assigned an age to the final visible annulus, while the age of fish collected during spring was estimated by including the edge of the otolith as the final annulus. Figure 1 represents a flathead catfish otolith image typical of older fish in our study, and annuli are indicated on the figure.

Growth analysis.-We fitted a von Bertalanffy growth equation with an additive error structure (Ricker 1975) to age data collected from each population. Nonlinear least-squares regression (NLIN procedure in the Statistical Analysis System; SAS Institute 1994) was used to fit the equation

$$
L_{t}=L_{\infty}\left[1-e^{k\left(t-t_{0}\right)}\right],
$$

where $L_{t}$ is the predicted length at a given time, $L_{\infty}$ is 
TABLE 3.-Extended.

\begin{tabular}{|c|c|c|c|c|c|c|c|c|c|}
\hline \multirow[b]{2}{*}{ Location and statistic } & \multicolumn{8}{|c|}{ Total length $(\mathrm{mm})$ at age } & \multirow[b]{2}{*}{ Reference } \\
\hline & 10 & 11 & 12 & 13 & 14 & 15 & 16 & 17 & \\
\hline Neuse River, North Carolina & 798 & 851 & 858 & 977 & 1,020 & & & & Current study \\
\hline Northeast Cape Fear River, North Carolina & 854 & 905 & 961 & 1,018 & 1,029 & 1,066 & 1,108 & 1,150 & Current study \\
\hline Lumber River, North Carolina & 747 & 796 & 965 & & & & & & Current study \\
\hline Altamaha River, Georgia ${ }^{a}$ & 717 & 755 & 849 & 901 & 879 & 922 & 647 & & Gabrowski et al. (2004) \\
\hline Ocmulgee River, Georgia & 1,012 & 1,081 & 1,178 & 1,321 & 1,665 & 1,761 & 1,800 & & Nash (1999) \\
\hline Edisto River, South Carolina & & & & & & & & & Bulak and Leitner (1999) \\
\hline $\begin{array}{l}\text { Little River and Long Cane, } \\
\text { South Carolina }\end{array}$ & 1,129 & 984 & 940 & & 940 & & & & Bulak and Leitner (1999) \\
\hline Great Pee Dee River, South Carolina & 770 & 713 & & 901 & 1,101 & & & & Bulak and Leitner (1999) \\
\hline Flint River, Georgia & & & & & & & & & Quinn (1989) \\
\hline Cape Fear River, North Carolina & & & & & & & & & Guier et al. (1984) \\
\hline Colorado River, Arizona-California & & & & & & & & & Young and Marsh (1990) \\
\hline Verde River, Arizona & & & & & & & & & Young and Marsh (1990) \\
\hline Coachella Canal, California & & & & & & & & & Pisano et al. (1983) \\
\hline Mean & 885.0 & 888.3 & 980.4 & $1,054.1$ & $1,151.0$ & $1,413.7$ & $1,454.1$ & $1,150.0$ & \\
\hline SE & 62.3 & 53.9 & 53.0 & 92.2 & 131.0 & 347.3 & 141.2 & & \\
\hline
\end{tabular}

the average maximum size in the population, $k$ is the growth coefficient, $t$ is time (years), and $t_{0}$ is the hypothetical age (years) when the mean fish total length is zero. We then compared growth rates by estimating the mean length at age 1 through the maximum age in each population based on this growth model. A nonparametric $F$-test for comparing parameters from nonlinear models was used to test for growth differences between the populations based on the von Bertalanffy growth parameters (Ratkowsky 1983). This procedure involves testing the hypothesis that a common growth curve is adequate to fit data from each of the three study populations. If the common growth curve hypothesis is rejected, then a series of morerestrictive models and hypotheses that omit parameters and populations are compared to elucidate differences

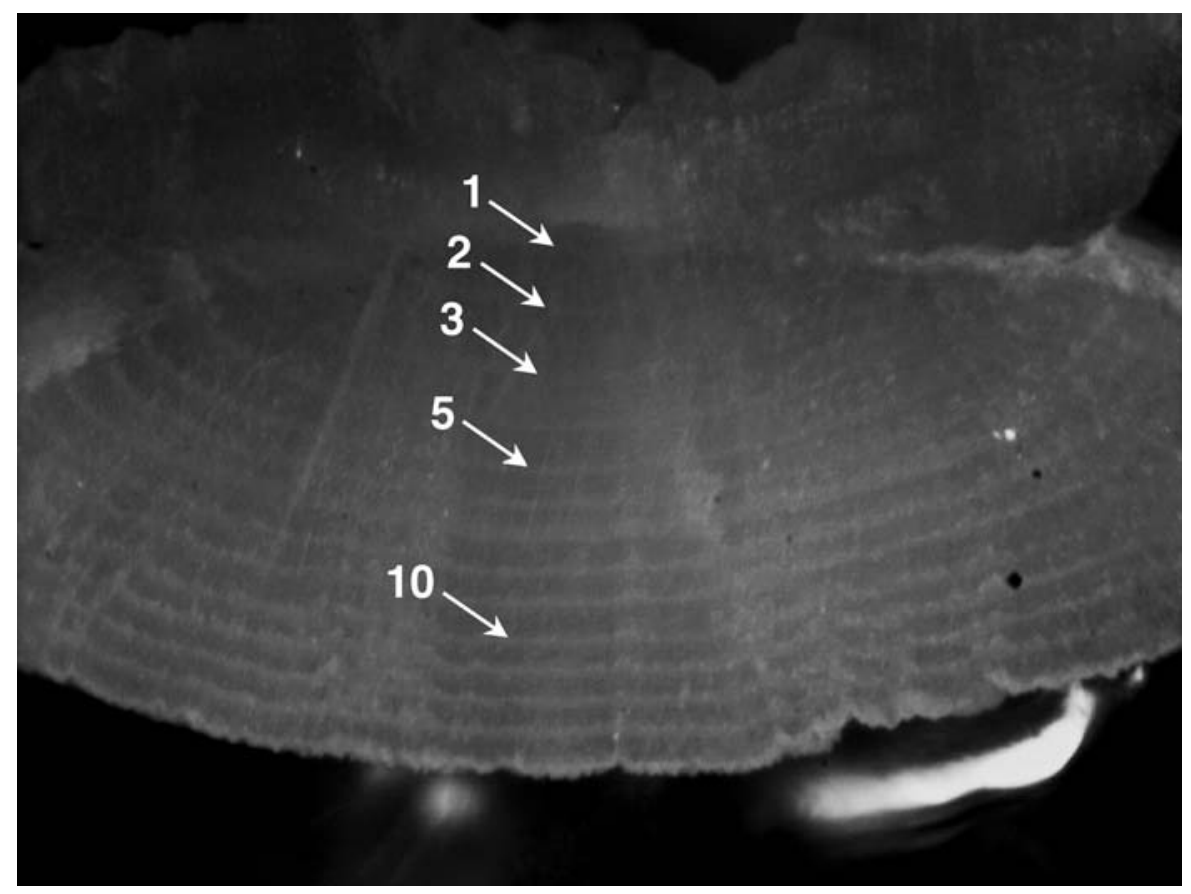

FIGURE 1.- Image of a sectioned otolith extracted from a female flathead catfish (1,055 mm total length; $21,300 \mathrm{~g})$ collected on 7 May 2003 from the Northeast Cape Fear River, North Carolina. Estimated age is 14 years. 

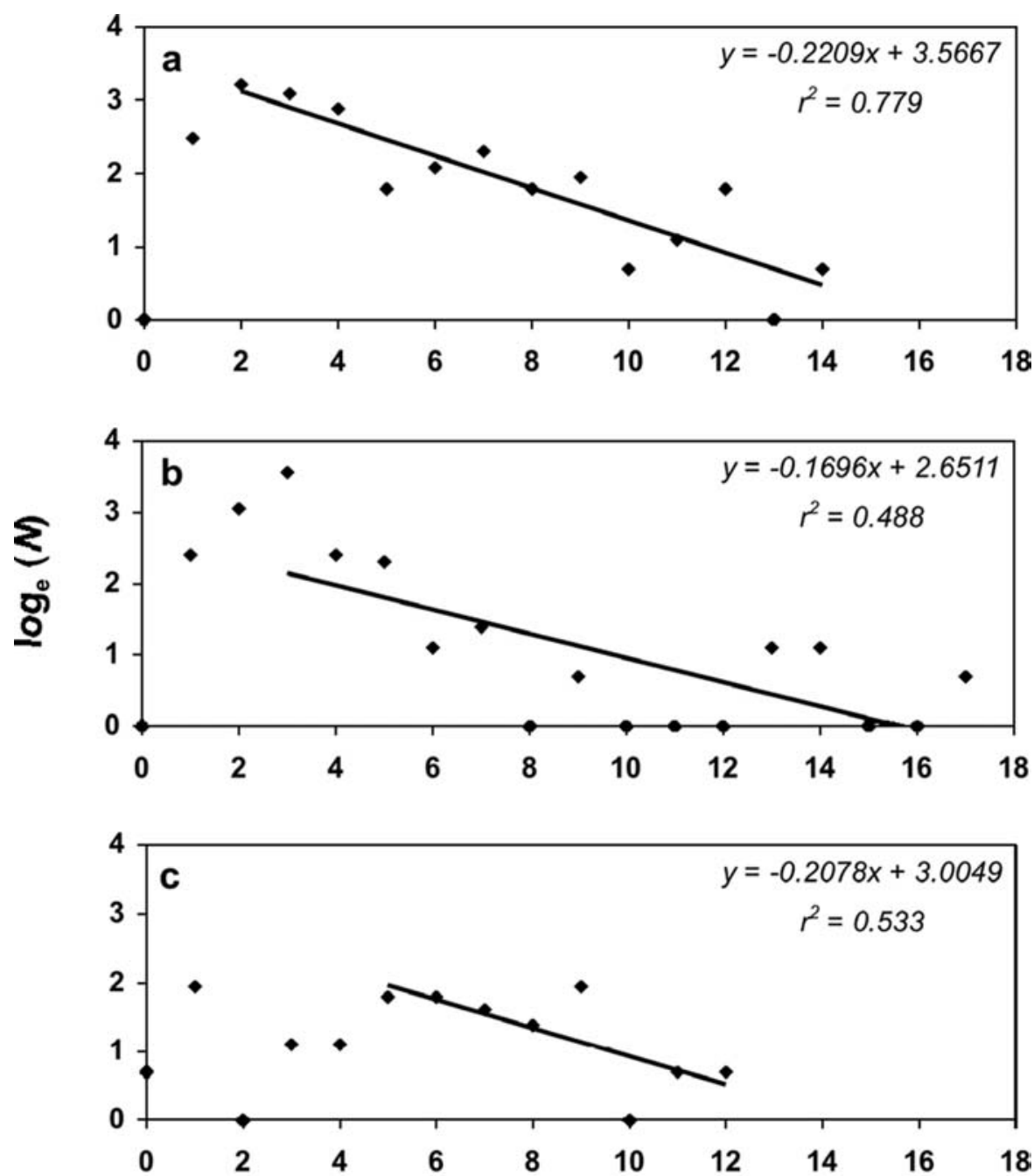

Age (years)

FIGURE 2.-Catch curves for flathead catfish collected in the (a) Neuse River, (b) Northeast Cape Fear River, and (c) Lumber River, North Carolina, during 2001-2003.

in growth parameters among populations. Our sample sizes of fish with known sex were not sufficient to compare growth rates between sexes. However, other researchers detected no significant difference in growth between sexes for an introduced riverine population of flathead catfish (Grabowski et al. 2004), and thus we included all collected fish in a single group for growth analyses.

Mortality estimation.-The mode of the $\log _{e}$ (number of fish collected +1 ) versus age plot (i.e., catch curve) was used to determine the age at which flathead catfish fully recruited to the gear (Figure 2). In- stantaneous total mortality rate $(Z)$ was estimated by the slope of a linear regression fitted to the descending right limb of each catch curve (Figure 2) (Ricker 1975; Seber 1982). The annual total mortality rate $(A=1-$ $e^{-z}$ ) was then calculated based on the estimate of $Z$ (Ricker 1975). The mode of the age-frequency plot used to represent age at full recruitment (i.e., threshold age; Seber 1982) varied among populations (Figure 2). The distribution was multimodal for Lumber River flathead catfish (ages 1, 5-6, and 9; Figure 2c), and we initiated the catch curve at age 5 for that population. Such irregularities represent variation in fish recruit- 
TABLE 4.-Flathead catfish size and age summary, growth parameters (95\% confidence limits in parentheses), and mortality estimates for three North Carolina rivers sampled in 2001-2003. $\left(L_{\infty}=\right.$ asymptotic length; $k=$ growth coefficient; $t_{0}=$ hypothetical age at which fish length $=0 ; Z=$ instantaneous total mortality rate; $A=$ annual total mortality rate).

\begin{tabular}{lccc}
\hline & \multicolumn{3}{c}{ River } \\
\cline { 2 - 4 } \multicolumn{1}{c}{ Variable } & Lumber & Northeast Cape Fear & Neuse \\
\hline Sample size & 36 & 94 & 114 \\
Age (years) & & & \\
$\quad$ Mean & 5.7 & 2.9 & 4.6 \\
SD & 3.1 & $1-17$ & 3.1 \\
$\quad$ Range & $0-12$ & 397 & $1-14$ \\
Total length (mm) & 508 & 250 & 515 \\
$\quad$ Mean & 237 & $123-1,150$ & 227 \\
SD & $124-965$ & 1,423 & $150-1,165$ \\
Range & 1,233 & $(1,206,1,640)$ & 961 \\
Growth parameters & $(447,2,019)$ & 0.11 & $(843,1,079)$ \\
$L_{\infty}$ (mm) & 0.09 & $(0.08,0.14)$ & 0.20 \\
$\quad k$ & $(-0.01,0.19)$ & 0.45 & $(0.13,0.27)$ \\
& -0.42 & $(0.15,0.75)$ & -0.03 \\
$t_{0}$ (years) & $(-1.46,0.62)$ & -0.170 & $(-0.50,0.44)$ \\
Mortality parameters & -0.208 & $(-0.275,-0.065)$ & $(-0.301,-0.141)$ \\
$Z$ & $(-0.401,-0.015)$ & 0.156 & 0.198 \\
\hline
\end{tabular}

ment among years and do not greatly affect the value of the catch curve (Ricker 1975).

\section{Results \\ Age and Growth}

Flathead catfish of wide age and size ranges were collected in each river (Table 4). Those from the NECFR exhibited the fastest growth rates, but only 10 fish older than age 5 were collected, thus limiting analyses of older fish (Table 5). The four most recent age-classes (1998-2001) showed slower growth than those cohorts previous to the 1998 year-class, while the 1996 year-class consistently showed the fastest growth among all cohorts in that river. Growth rates were rapid through age 5; fish generally grew at least $100 \mathrm{~mm} /$ year during that period. Growth rates were fairly constant between ages 6 and 13, averaging about $50 \mathrm{~mm} /$ year, but slowed slightly beyond those ages (Table 5).

Back-calculated growth of Neuse River flathead catfish revealed slower growth to age 1 for the five most recent year-classes (1996-2000) than for yearclasses previous to 1996 (Table 6). Growth to successive ages was similar among all age-classes except the 1989 year-class, which consistently grew slower owing to an artifact of one slow-growing fish. Annual growth increments steadily declined through age 5 but remained similar between ages 6 and 11 (Table 6). Low sample sizes for age-12 and older fish hindered comparisons beyond age 11 .
Flathead catfish of the Lumber River showed fairly similar growth rates among all age- and size-classes, and slightly slower growth was found for the 1992, 1994, 2000, and 2001 year-classes (Table 7). Similar to the NECFR population, the 1996 cohort in the Lumber River exhibited the fastest growth rates among all ageclasses. The growth rate declined sharply between ages 1 and 2 and varied between 72 and $98 \mathrm{~mm} /$ year through age 6. Growth rates in the Lumber River were the slowest among the three populations studied.

Von Bertalanffy growth models generally fit the NECFR and Neuse River populations fairly well through age 8 (Table 4; Figure 3). Lower sample sizes and greater variation in growth rate at large sizes reduced model fit at older ages. Growth rates among rivers were significantly different in an overall comparison $\left(F_{6,232}=12.6, P<0.0001\right)$ as well as in pairwise comparisons (Neuse River versus NECFR: $F_{3,202}=30.4, P<0.0001$; Neuse River versus Lumber River: $F_{3,146}=32.8, P<0.0001$; NECFR versus Lumber River: $\left.F_{3,144}=27.1, P<0.0001\right)$. Backcalculated and von Bertalanffy-modeled growth rates were very similar between ages 1 and 11 in the Lumber River (Figure 3). Back-calculated growth was similar to modeled growth in the NECFR until age 6 , when back-calculated growth slowed. Back-calculated growth was generally slower than modeled growth in the Neuse River between ages 3 and 10 but was higher for ages 13 and 14. The von Bertalanffy growth model 
TABLE 5.-Average back-calculated total length (TL $[\mathrm{mm}]$ ) of flathead catfish collected from the Northeast Cape Fear River, North Carolina, 2002-2003.

\begin{tabular}{|c|c|c|c|c|c|c|c|c|c|c|c|}
\hline \multirow{2}{*}{$\begin{array}{l}\text { Year-class } \\
\text { and summary } \\
\text { TL statistic }{ }^{\mathrm{a}}\end{array}$} & \multirow[b]{2}{*}{$N$} & \multirow{2}{*}{$\begin{array}{l}\text { Mean TL } \\
\text { at capture }\end{array}$} & \multirow{2}{*}{$\begin{array}{c}\mathrm{TL} \\
\text { range }\end{array}$} & \multicolumn{8}{|c|}{ TL at age } \\
\hline & & & & 1 & 2 & 3 & 4 & 5 & 6 & 7 & 8 \\
\hline 2001 & 10 & 152 & $123-197$ & 128 & & & & & & & \\
\hline 2000 & 20 & 223 & $140-361$ & 132 & 219 & & & & & & \\
\hline 1999 & 34 & 312 & $209-579$ & 136 & 224 & 293 & & & & & \\
\hline 1998 & 10 & 488 & $385-569$ & 175 & 289 & 372 & 444 & & & & \\
\hline 1997 & 9 & 663 & $610-710$ & 208 & 351 & 457 & 548 & 624 & & & \\
\hline 1996 & 2 & 697 & $678-716$ & 222 & 372 & 465 & 558 & 630 & 716 & & \\
\hline 1995 & 3 & 750 & $633-914$ & 199 & 294 & 406 & 498 & 571 & 646 & 702 & \\
\hline 1994 & 0 & & & & & & & & & & \\
\hline 1993 & 1 & 995 & 995 & 216 & 355 & 463 & 540 & 625 & 717 & 802 & 879 \\
\hline 1992 & 0 & & & & & & & & & & \\
\hline 1991 & 0 & & & & & & & & & & \\
\hline 1990 & 0 & & & & & & & & & & \\
\hline 1989 & 2 & 1,098 & $1,080-1,115$ & 223 & 345 & 426 & 493 & 566 & 642 & 705 & 768 \\
\hline 1988 & 2 & 1,056 & $1,055-1,057$ & 164 & 275 & 380 & 459 & 524 & 590 & 645 & 694 \\
\hline 1987 & 0 & & & & & & & & & & \\
\hline 1986 & 0 & & & & & & & & & & \\
\hline 1985 & 1 & 1,150 & 1,150 & 216 & 348 & 453 & 523 & 585 & 641 & 697 & 739 \\
\hline $\begin{array}{l}\text { Weighted mean } \\
\text { TL at age }\end{array}$ & & & & $\begin{array}{r}153.5 \\
(8.0)\end{array}$ & $\begin{array}{r}257.4 \\
(11.4)\end{array}$ & $\begin{array}{l}350.9 \\
(14.5)\end{array}$ & $\begin{array}{l}498.4 \\
(14.6)\end{array}$ & $\begin{array}{l}599.0 \\
(16.8)\end{array}$ & $\begin{array}{l}653.9 \\
(25.6)\end{array}$ & $\begin{array}{l}700.7 \\
(28.6)\end{array}$ & $\begin{array}{l}757.1 \\
(28.2)\end{array}$ \\
\hline $\begin{array}{l}\text { Mean annual } \\
\text { increment }\end{array}$ & & & & $\begin{array}{r}153.5 \\
(8.0)\end{array}$ & $\begin{array}{r}103.9 \\
(13.9)\end{array}$ & $\begin{array}{c}93.5 \\
(18.4)\end{array}$ & $\begin{array}{l}147.5 \\
(20.6)\end{array}$ & $\begin{array}{l}100.6 \\
(22.3)\end{array}$ & $\begin{array}{c}54.9 \\
(30.7)\end{array}$ & $\begin{array}{c}46.8 \\
(38.4)\end{array}$ & $\begin{array}{r}56.4 \\
(40.2)\end{array}$ \\
\hline
\end{tabular}

estimated the largest theoretical size for the NECFR population followed by the Lumber and Neuse river populations, and growth coefficients varied among rivers, indicating differing rates of increase in fish length and differing shapes of growth curves.

\section{Mortality}

Mortality estimates derived from catch curves were relatively consistent among rivers (Table 4). Instantaneous total mortality rates ranged from 0.17 to 0.22 , and annual total mortality rates ranged from 0.16 to 0.20 (i.e., 16-20\%). Low catch rates of older fish (ages 8 and older) and variation among cohorts decreased the precision of our mortality estimates, and $95 \%$ confidence intervals averaged $\pm 60 \%$ of the associated $Z$ estimates. We detected no significant difference in $Z$ among populations by analysis of covariance $\left(F_{2,20}=\right.$ $1.23, P=0.29$ ), and $95 \%$ confidence intervals for all estimates overlapped the means of the other two estimates.

\section{Discussion}

We observed a large range in sizes at each age within and among the rivers we sampled. For example, the total length of age- 3 fish from the Neuse River ranged from 285 to $560 \mathrm{~mm}$, and 600-mm fish from the Neuse River spanned ages from 3 to 9 years (Figure 3). These large variations could be attributable to differential growth or mortality rates among cohorts or age estimation error. Larger sample sizes of fish for age analysis would further determine the source of this wide variation, but results from other populations suggest that high within-population variance in growth rate is common for this species (Cross and Hastings 1956; Layher and Boles 1980; Winkelman 2002; Grabowski et al. 2004).

\section{Growth}

Growth comparisons among flathead catfish populations within a study or among published results should consider the bony structure used for age estimates. Pectoral spines have frequently been used to age flathead catfish and are considered the hard part of choice for the majority of studies, due to logistic simplicity and nonlethal effects. However, Nash and Irwin (1999) demonstrated potential bias and reduced precision in flathead catfish age analysis based on pectoral spines versus otoliths. Our research is one of only a few studies conducted on flathead catfish that did not rely upon spines or vertebrae as aging structures, and many previous studies may be variably biased, especially for results on older fish (ages over 5 years; Nash and Irwin 1999). However, annulus formation in the articulating process of the pectoral spine was validated for flathead catfish to age 5 (Turner 1982), and age estimates derived from the pectoral spine articulating process are more accurate and precise than those derived from pectoral spine basal recess 
TABLE 5.-Extended.

\begin{tabular}{|c|c|c|c|c|c|c|c|c|c|}
\hline \multirow{2}{*}{$\begin{array}{l}\text { Year-class } \\
\text { and summary } \\
\text { TL statistic }\end{array}$} & \multicolumn{9}{|c|}{$\mathrm{TL}$ at age } \\
\hline & 9 & 10 & 11 & 12 & 13 & 14 & 15 & 16 & 17 \\
\hline \multicolumn{10}{|l|}{2001} \\
\hline \multicolumn{10}{|l|}{2000} \\
\hline \multicolumn{10}{|l|}{1999} \\
\hline \multicolumn{10}{|l|}{1998} \\
\hline \multicolumn{10}{|l|}{1997} \\
\hline \multicolumn{10}{|l|}{1996} \\
\hline 1995 & & & & & & & & & \\
\hline \multicolumn{10}{|l|}{1994} \\
\hline 1993 & 949 & & & & & & & & \\
\hline \multicolumn{10}{|l|}{1992} \\
\hline 1991 & & & & & & & & & \\
\hline \multicolumn{10}{|l|}{1990} \\
\hline 1989 & 836 & 908 & 959 & 1,023 & 1,082 & & & & \\
\hline 1988 & 749 & 812 & 872 & 924 & 978 & 1,035 & & & \\
\hline \multicolumn{10}{|l|}{1987} \\
\hline 1986 & & & & & & & & & \\
\hline 1985 & 781 & 829 & 864 & 913 & 969 & 1,018 & 1,066 & 1,108 & 1,150 \\
\hline $\begin{array}{l}\text { Weighted mean } \\
\text { TL at age }\end{array}$ & $\begin{array}{l}790.1 \\
(31.4)\end{array}$ & $\begin{array}{l}854.2 \\
(24.2)\end{array}$ & $\begin{array}{l}905.4 \\
(23.5)\end{array}$ & $\begin{array}{l}961.2 \\
(26.7)\end{array}$ & $\begin{array}{r}1,017.8 \\
(28.3)\end{array}$ & $\begin{array}{r}1,029.1 \\
(13.0)\end{array}$ & $1,066.4$ & $1,108.2$ & $1,150.0$ \\
\hline $\begin{array}{c}\text { Mean annual } \\
\text { increment }\end{array}$ & $\begin{array}{c}33.0 \\
(42.2)\end{array}$ & $\begin{array}{c}64.0 \\
(39.6)\end{array}$ & $\begin{array}{l}51.2 \\
(33.7)\end{array}$ & $\begin{array}{c}55.8 \\
(35.6)\end{array}$ & $\begin{array}{l}56.6 \\
(38.9)\end{array}$ & $\begin{array}{c}11.3 \\
(31.1)\end{array}$ & $\begin{array}{c}37.3 \\
(13.0)\end{array}$ & 41.8 & 41.8 \\
\hline
\end{tabular}

sections (Nash and Irwin 1999). Furthermore, ages estimated from pectoral spines for young fish are relatively accurate, and the general direction of bias in older fish ages is known (underestimates of older fish based on spines; Nash and Irwin 1999). Therefore, age estimates derived from pectoral spines in previous studies remain useful for discerning patterns among flathead catfish populations when proper scrutiny is used in their interpretation.

In general, the observed growth of introduced flathead catfish populations in North Carolina rivers is slower than that of other introduced populations throughout the southeastern United States but faster than that of most native riverine populations (Tables 1 ,

TABLE 6.-Average back-calculated total length (TL [mm]) of flathead catfish collected from the Neuse River, North Carolina, 2001-2003.

\begin{tabular}{|c|c|c|c|c|c|c|c|c|c|c|c|c|c|c|c|c|c|}
\hline \multirow{2}{*}{$\begin{array}{l}\text { Year-class } \\
\text { and summary } \\
\text { TL statistic }\end{array}$} & \multirow{2}{*}{\multicolumn{2}{|c|}{$\begin{array}{r}\text { Mean TL } \\
N \text { at capture }\end{array}$}} & \multirow{2}{*}{$\begin{array}{c}\mathrm{TL} \\
\text { range }\end{array}$} & \multicolumn{14}{|c|}{ TL at age } \\
\hline & & & & 1 & 2 & 3 & 4 & 5 & 6 & 7 & 8 & 9 & 10 & 11 & 12 & 13 & 14 \\
\hline 2000 & 11 & 191 & $150-222$ & 134 & & & & & & & & & & & & & \\
\hline 1999 & 24 & 302 & $240-380$ & 191 & 270 & & & & & & & & & & & & \\
\hline 1998 & 21 & 448 & $285-588$ & 189 & 309 & 391 & & & & & & & & & & & \\
\hline 1997 & 17 & 548 & $375-638$ & 188 & 303 & 389 & 467 & & & & & & & & & & \\
\hline 1996 & 5 & 628 & $570-679$ & 186 & 314 & 419 & 499 & 576 & & & & & & & & & \\
\hline 1995 & 7 & 669 & $593-742$ & 222 & 364 & 455 & 529 & 586 & 641 & & & & & & & & \\
\hline 1994 & 9 & 697 & $554-918$ & 220 & 339 & 432 & 520 & 596 & 659 & 717 & & & & & & & \\
\hline 1993 & 5 & 820 & $690-918$ & 209 & 342 & 448 & 530 & 596 & 660 & 714 & 767 & & & & & & \\
\hline 1992 & 5 & 695 & $600-1,050$ & 219 & 323 & 395 & 467 & 520 & 571 & 630 & 680 & 721 & & & & & \\
\hline 1991 & 2 & 785 & $646-924$ & 204 & 316 & 398 & 462 & 529 & 581 & 631 & 682 & 731 & 771 & & & & \\
\hline 1990 & 1 & 1,165 & 1,165 & & & 583 & 657 & 724 & 791 & 865 & 924 & 1,007 & 1,057 & 1,115 & & & \\
\hline 1989 & 6 & 857 & $577-1,115$ & 200 & 284 & 365 & 429 & 494 & 549 & 609 & 661 & 712 & 759 & 804 & 848 & & \\
\hline 1988 & 0 & & & & & & & & & & & & & & & & \\
\hline 1987 & 1 & 1,020 & 1,020 & & 318 & 398 & 463 & 535 & 608 & 658 & 709 & 767 & 825 & 868 & 919 & 977 & 1,020 \\
\hline $\begin{array}{c}\text { Weighted mean } \\
\text { TL at age }\end{array}$ & & & & $\begin{array}{r}191.5 \\
(6.1)\end{array}$ & $\begin{array}{r}306.4 \\
\quad(7.9)\end{array}$ & $\begin{array}{l}407.3 \\
(10.8)\end{array}$ & $\begin{array}{l}489.9 \\
(13.3)\end{array}$ & $\begin{array}{l}566.2 \\
(16.4)\end{array}$ & $\begin{array}{l}622.9 \\
(21.3)\end{array}$ & $\begin{array}{l}676.2 \\
(28.0)\end{array}$ & $\begin{array}{l}710.1 \\
(37.5)\end{array}$ & $\begin{array}{l}740.8 \\
(52.2)\end{array}$ & $\begin{array}{l}798.0 \\
(60.6)\end{array}$ & $\begin{array}{l}850.7 \\
(75.3)\end{array}$ & $\begin{array}{l}858.0 \\
(78.9)\end{array}$ & 977.0 & $1,020.0$ \\
\hline $\begin{array}{l}\text { Mean annual } \\
\text { increment }\end{array}$ & & & & $\begin{array}{r}191.5 \\
(6.1)\end{array}$ & $\begin{array}{l}115.0 \\
(10.0)\end{array}$ & $\begin{array}{l}100.8 \\
(13.4)\end{array}$ & $\begin{array}{r}82.6 \\
(17.1)\end{array}$ & $\begin{array}{r}76.3 \\
(21.1)\end{array}$ & $\begin{array}{c}56.7 \\
(26.8)\end{array}$ & $\begin{array}{r}53.3 \\
(35.2)\end{array}$ & $\begin{array}{r}33.8 \\
(46.9)\end{array}$ & $\begin{array}{c}30.7 \\
(64.3)\end{array}$ & $\begin{array}{c}57.2 \\
(80.0)\end{array}$ & $\begin{array}{c}52.7 \\
(96.7)\end{array}$ & $\begin{array}{c}7.3 \\
(109.1)\end{array}$ & $\begin{array}{l}119.0 \\
(78.9)\end{array}$ & 43.0 \\
\hline
\end{tabular}

\footnotetext{
${ }^{a}$ Values in parentheses are SEs; those for the mean annual increment were calculated by pooling variance estimates of weighted mean TL at age according to Zar (1996).
} 
TABLE 7.-Average back-calculated total length (TL $[\mathrm{mm}]$ ) of flathead catfish collected from the Lumber River, North Carolina, during May 2003.

\begin{tabular}{|c|c|c|c|c|c|c|c|c|c|c|c|c|c|c|c|}
\hline \multirow{2}{*}{$\begin{array}{l}\text { Year-class } \\
\text { and summary } \\
\text { TL statistic }\end{array}$} & \multirow{2}{*}{\multicolumn{2}{|c|}{$\begin{array}{cc} & \text { Mean } \\
& \text { TL } \\
& \text { at } \\
N \quad \text { capture }\end{array}$}} & \multirow[b]{2}{*}{$\begin{array}{l}\mathrm{TL} \\
\text { range }\end{array}$} & \multicolumn{12}{|c|}{$\mathrm{TL}$ at age } \\
\hline & & & & 1 & 2 & 3 & 4 & 5 & 6 & 7 & 8 & 9 & 10 & 11 & 12 \\
\hline 2002 & 6 & 142 & 124-189 & 142 & & & & & & & & & & & \\
\hline 2001 & 1 & 190 & 190 & 122 & 190 & & & & & & & & & & \\
\hline 2000 & 2 & 276 & $263-289$ & 127 & 206 & 276 & & & & & & & & & \\
\hline 1999 & 2 & 384 & $350-417$ & 149 & 244 & 317 & 384 & & & & & & & & \\
\hline 1998 & 5 & 426 & $388-475$ & 142 & 229 & 308 & 367 & 424 & & & & & & & \\
\hline 1997 & 5 & 633 & $469-772$ & 185 & 289 & 367 & 495 & 564 & 631 & & & & & & \\
\hline 1996 & 4 & 725 & $689-770$ & 186 & 310 & 416 & 517 & 596 & 658 & 725 & & & & & \\
\hline 1995 & 3 & 696 & $636-783$ & 187 & 285 & 378 & 455 & 525 & 580 & 633 & 692 & & & & \\
\hline 1994 & 6 & 667 & $514-802$ & 159 & 232 & 314 & 402 & 467 & 519 & 567 & 616 & 667 & & & \\
\hline 1993 & 0 & & & & & & & & & & & & & & \\
\hline 1992 & 1 & 680 & 680 & & & & 349 & 421 & 465 & 519 & 564 & 608 & 644 & 680 & \\
\hline 1991 & 1 & 965 & 965 & 177 & 319 & 425 & 496 & 567 & 620 & 682 & 735 & 788 & 850 & 912 & 965 \\
\hline $\begin{array}{l}\text { Weighted mean } \\
\text { TL at age }\end{array}$ & & & & $\begin{array}{r}159.9 \\
(8.2)\end{array}$ & $\begin{array}{l}258.1 \\
(12.7)\end{array}$ & $\begin{array}{l}345.1 \\
(14.1)\end{array}$ & $\begin{array}{l}435.8 \\
(15.8)\end{array}$ & $\begin{array}{l}507.4 \\
(18.4)\end{array}$ & $\begin{array}{l}586.1 \\
(22.7)\end{array}$ & $\begin{array}{l}626.8 \\
(22.9)\end{array}$ & $\begin{array}{l}643.1 \\
(26.6)\end{array}$ & $\begin{array}{l}675.0 \\
(29.3)\end{array}$ & $\begin{array}{l}747.1 \\
(103.0)\end{array}$ & $\begin{array}{c}795.9 \\
(115.9)\end{array}$ & 965.0 \\
\hline $\begin{array}{l}\text { Mean annual } \\
\text { increment }(\mathrm{mm})\end{array}$ & & & & $\begin{array}{r}159.9 \\
(8.2)\end{array}$ & $\begin{array}{c}98.2 \\
(15.1)\end{array}$ & $\begin{array}{r}87.0 \\
(18.9)\end{array}$ & $\begin{array}{c}90.7 \\
(21.2)\end{array}$ & $\begin{array}{r}71.6 \\
(24.2)\end{array}$ & $\begin{array}{r}78.7 \\
(29.2)\end{array}$ & $\begin{array}{c}40.7 \\
(32.2)\end{array}$ & $\begin{array}{c}16.3 \\
(35.1)\end{array}$ & $\begin{array}{r}32.0 \\
(39.5)\end{array}$ & $\begin{array}{c}72.0 \\
(107.0)\end{array}$ & $\begin{array}{c}48.9 \\
(155.1)\end{array}$ & $\begin{array}{c}169.1 \\
(115.9)\end{array}$ \\
\hline
\end{tabular}

${ }^{a}$ Values in parentheses are SEs; those for the mean annual increment were calculated by pooling variance estimates of weighted mean TL at age according to Zar (1996).

3). Growth to quality size generally occurred by age 5 in our study but was attained as early as age 3 in another Atlantic slope introduced population in the Ocmulgee River, Georgia (Nash 1999). Memorable sizes were reached between ages 11 and 12 in our study rivers versus age 8 in the Ocmulgee River. Trophy-size fish (1,020 mm; Quinn 1991) were observed by age 11 in the Ocmulgee River, whereas this size was attained by age 14 in the Neuse River and NECFR (Table 3). We collected no trophy-size fish in the Lumber River.

Growth rates of North Carolina coastal plain flathead catfish are considerably faster than those reported from the Tallapoosa River, Alabama, in the only comparable native flathead catfish age and growth study that used otoliths (Nash 1999). Growth rates in our study are also faster than those reported from riverine populations throughout the Upper Midwest (Table 1); however, among other factors, this comparison may reflect counter-gradient growth variation, which would predict faster growth in more southerly latitudes. Our growth rates were most similar to reservoir flathead catfish in their native range (Table 2).

Growth rates after age 2 in the Cape Fear River (Guier et al. 1984) were much higher than those reported here (Table 3 ). This may be partially attributed to the use of pectoral spines (versus otoliths) to estimate ages or could reflect actual spatial or temporal variation. However, there is compelling evidence to suggest that fish in the earlier study grew faster as a result of their more-recent establishment than the populations we studied in the Neuse River and NECFR. Guier et al. (1984) reported that flathead catfish were first introduced into the Cape Fear River in 1966 , only 13 years before their study. As an introduced population expands and decimates its initial food supply, growth is likely to slow due to intraspecific competition and other density-dependent factors. Layher and Boles (1980) reported that flathead catfish became almost entirely piscivorous at $500 \mathrm{~mm}$, as did the flathead catfish in our three study rivers (Pine 2003; Pine et al. 2005). Flathead catfish in the Guier et al. (1984) study showed growth that was accelerated relative to fish in our study beginning at around age 3, when flathead catfish averaged $497 \mathrm{~mm}$ and presumably became obligate piscivores. Quinn (1989) reported markedly slower growth rates in the Flint River during a 1985 study than was observed in previous work from the 1970s. Similar trends may develop in other introduced flathead catfish populations, where growth rates may slow and approach those of native populations over time.

\section{Trends among Populations}

Comparisons among growth rates reported for flathead catfish in rivers versus reservoirs and native versus introduced populations reveal several trends (Figure 4). Native flathead catfish growth in reservoirs was faster on average than that of riverine populations (Tables 1, 2). Fish averaged $566 \mathrm{~mm}$ at age 5 in reservoirs but only $481 \mathrm{~mm}$ in rivers, and $700 \mathrm{~mm}$ was attained between ages 5 and 9 for reservoir fish and between ages 6 and 20 for riverine fish. In general, introduced riverine populations show faster growth 

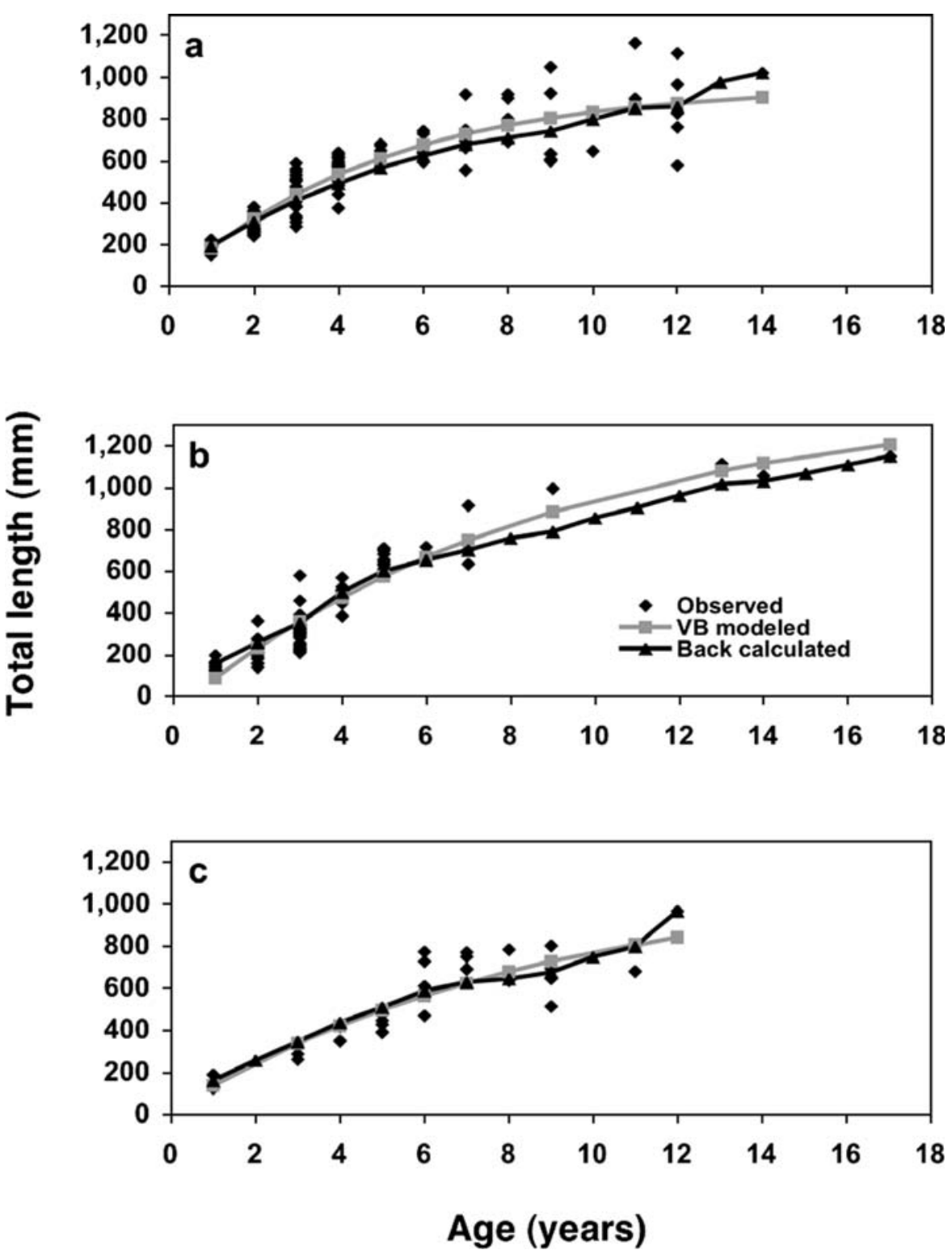

FIGURE 3.-Comparison of observed, von Bertalanffy (VB)-modeled, and back-calculated total length at age for flathead catfish collected in the (a) Neuse River, (b) Northeast Cape Fear River, and (c) Lumber River, North Carolina, during 2001-2003.

rates than do native riverine populations (Tables 1, 3; Figure 4).

While the data resolution among studies precluded specific statistical comparisons, an examination of means and confidence intervals suggests that growth rates between native and introduced riverine populations are statistically different (Figure 4). For all ages up to age 9 , the confidence intervals for mean length at age for native riverine populations do not overlap those corresponding means for introduced riverine populations (and vice versa), and means for reservoir fishes are intermediate to those for riverine fishes. At ages 9 and 10, the means of fish length for introduced river populations and those of native reservoirs converge, which may either suggest ecological variation or be an artifact of methodological differences in structures used for age estimation. The trends that we have detected among studies suggest that while differences in 


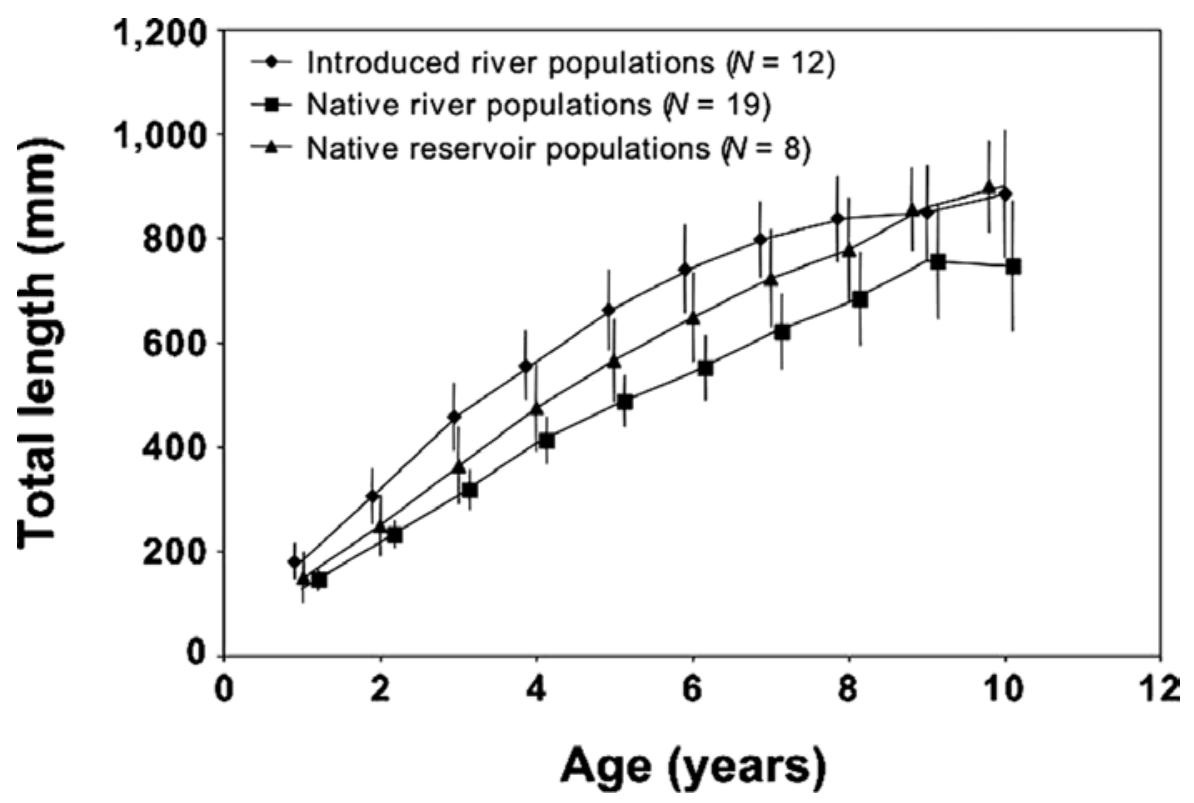

FIGURE 4.- Mean total length at age (and 95\% confidence intervals) of introduced riverine, native riverine, and native reservoir flathead catfish populations in the USA, indicating variable growth rates between native and introduced populations and between riverine and reservoir populations (see Tables 1-3 for summary according to population).

flathead catfish growth among aquatic habitats (rivers and reservoirs) and native and introduced populations may not be consistently statistically significant, they are probably biologically significant, and we expect that future results will increase sample sizes and reduce confidence intervals to yield greater statistical differentiation.

Previous to our collection of a 17-year-old flathead catfish in the NECFR, the maximum age reported for an introduced riverine population (16 years) came from the Ocmulgee River, and the maximum length obtained remains $1,800 \mathrm{~mm}$ from that population (Nash 1999). All introduced riverine populations yielded quality-size fish by age 5 and memorable-size fish by age 8 , while the Ocmulgee River population grew trophy-size fish by age 11. Introduced riverine populations in the southeastern USA (Guier et al. 1984; Quinn 1989; Bulak and Leitner 1999; Nash 1999; our results) tended to grow faster than those from the western region of the country (Pisano et al. 1983; Young and Marsh 1990; Table 3).

Our literature review defined general trends in flathead catfish growth rates wherein populations in reservoirs grow faster than those in rivers, introduced populations grow faster than native populations, and eastern U.S. populations grow faster than those in western states. Exceptions to these trends include studies by Minckley and Deacon (1959), Francis
(1993), and Stauffer et al. (1996), who reported growth rates from native populations similar to those of introduced flathead catfish (Tables 1, 3). Possible explanations include the use of spines (versus otoliths) in each of these studies (which would result in biases lower in age and higher in associated growth estimates), particular complexities in predator-prey relationships, or other differences in local environmental conditions.

\section{Mortality}

The values of $A$ for flathead catfish in our study were lower than those that Robinson (1997) found for native populations in the Missouri and Mississippi rivers but similar to recent estimates from Oklahoma reservoirs (Winkelman 2002). Our estimates of $A$ for these three introduced riverine populations were relatively low, ranging from 0.16 to 0.20 (Table 4). The Neuse River population exhibited relatively constant mortality over the entire range of ages sampled $\left(r^{2}=0.78\right.$; Figure 2$)$. Annual mortality in the NECFR varied by age or possibly through time, and higher mortality was observed in recent years. The size structure of flathead catfish in this river indicates that fish may consistently be harvested once they reach $600 \mathrm{~mm}$. While conducting this research, we anecdotally observed a greater number of setlines (primarily attached to tree limbs) on the NECFR than on the other two rivers, 
which suggests fishing mortality as a partial explanation for the temporal variation and catch curve fit among rivers.

Stochastic mortality events may partially explain variation in flathead catfish population structure among the rivers we studied. The relatively young age structure in the NECFR may have partially been a result of Hurricane Fran, which devastated much of eastern North Carolina in 1996. Large fish kills were observed in this river due to anoxic ambient conditions associated with severe flooding during and after the storm (K. Nelson, North Carolina Wildlife Resources Commission, personal communication), and such a mortality event may have reduced recruitment and the adult flathead catfish population. Furthermore, land use on the North Carolina coastal plain is predominantly agricultural and includes numerous confined poultry and swine production facilities that are known to degrade river water quality and cause fish kills via diffuse and point releases of animal waste (Mallin 2000). Such primary and cumulative impacts on riverine fish populations in this region may lead to stochastic events that result in differential mortality among cohorts and over time. Such variation among cohorts and years complicates the utility of catch curve analysis for estimating $A$, as the assumed condition that mortality rate is uniform with age over the range of age-classes considered may be violated to varying degrees (Ricker 1975).

Although we were unable to separate natural and fishing mortality rates from our $A$ estimates, we suggest that fishing mortality is an important factor in maintaining the relatively low $A$ in these populations. Our $A$ estimates were similar to annual fishing mortality rates reported for the Flint River introduced flathead catfish population (Quinn 1993). In a radiotelemetry study associated with our research on the same three rivers (Kwak et al. 2004), only one instance of natural mortality was detected throughout the 1-year tracking study among 40 radio-tagged fish $(2.5 \%)$, and five angling mortalities (12.5\%) were reported during the 2-year period after fish were radio-tagged. In addition, radio signals were lost from eight fish during the 1-year tracking period. These fish may have permanently emigrated from our study areas, and some may have been undetected mortalities. The relatively low mortality rates of our radio-tagged fish are in accord with the similarly low estimates of annual fishing mortality (14-25\%) reported by Quinn (1993) for another introduced flathead catfish population and support the validity of our $16-20 \%$ estimates of $A$ derived from catch curve analyses (Table 4).

\section{Conclusions}

Our age, growth, and mortality research on these three populations of flathead catfish in North Carolina coastal plain rivers represents one of several studies of such introduced populations for which data accuracy and precision are presumed to be reasonable to form scientific conclusions. Our literature review and compilation revealed important trends in flathead catfish growth rates as related to population origin (native or introduced), habitat (lentic or lotic), and geography (region of the USA). Our results conformed to the expectation that growth rates in these populations would be higher than those of native riverine populations, but growth was generally slower than that of other introduced flathead catfish populations in the southeastern USA, contrary to our prediction. Elucidating such trends among native and introduced populations, aquatic habitats, and geographic regions greatly enhances our understanding of and ability to manage this ecologically, economically, and culturally important species, and we look forward to future research to further refine these relationships.

\section{Acknowledgments}

We thank biologists and administrators of the North Carolina Wildlife Resources Commission, especially Keith Ashley, Tom Rachels, and Christian Waters, for suggestions in study design, site selection, and field assistance. Drew Dutterer and Ed Malindzak provided helpful field and laboratory assistance. We thank Dave Buckmeier and Jeff Jolley for guidance in otolith preparation and age estimation procedures. Joe Hightower, Rich Noble, and Jim Rice offered ongoing discussion and insight that improved study design, interpretation, and presentation. This research was funded by the North Carolina Wildlife Resources Commission through Federal Aid in Sport Fish Restoration funds (Project F-68).

\section{References}

Barnickol, P. G., and W. C. Starrett. 1951. Commercial and sport fishes of the Mississippi River between Caruthersville, Missouri, and Dubuque, Iowa. Bulletin of the Illinois Natural History Survey 25:267-350.

Bulak, J. S., and J. K. Leitner. 1999. A comparison of age and growth of three flathead catfish populations in South Carolina. Page 513 in E. R. Irwin, W. A. Hubert, C. F. Rabeni, H. L. Schramm, Jr., and T. Coon, editors. Catfish 2000: proceedings of the international ictalurid symposium. American Fisheries Society, Symposium 24, Bethesda, Maryland.

Carlander, K. D. 1982. Standard intercepts for calculating length from scale measurements for some centrarchid and percid fishes. Transactions of the American Fisheries Society 111:332-336. 
Carroll, B. B., and G. E. Hall. 1964. Growth of catfishes in Norris Reservoir, Tennessee. Journal of the Tennessee Academy of Science 39:86-91.

Cross, F. B., and C. E. Hastings. 1956. Ages and sizes of 29 flathead catfish from the Kansas River, Douglas County, Kansas. Transactions of the Kansas Academy of Science 59:85-86.

Edmundson, J. P., Jr. 1974. Food habits, age, and growth of flathead catfish, Pylodictis olivaris (Rafinesque), in Bluestone Reservoir, West Virginia. West Virginia Division of Natural Resources, Charleston.

Francis, J. M. 1993. Recreational handgrabbing as a factor influencing flathead catfish stock characteristics in two Mississippi streams. Master's thesis. Mississippi State University, Mississippi State.

Grabowski, T. B., J. J. Isely, and R. R. Weller. 2004. Age and growth of flathead catfish, Pylodictus olivaris Rafinesque, in the Altamaha River system, Georgia. Journal of Freshwater Ecology 19:411-417.

Grussing, M. D., D. R. DeVries, and R. A. Wright. 2000. Stock characteristics and habitat use of catfishes in regulated sections of four Alabama rivers. Proceedings of the Annual Conference Southeastern Association of Fish and Wildlife Agencies 53(1999):15-34.

Guier, C. R., L. E. Nichols, and R. T. Rachels. 1984. Biological investigation of flathead catfish in the Cape Fear River. Proceedings of the Annual Conference Southeastern Association of Fish and Wildlife Agencies 35(1981):607-621.

Hargis, H. L. 1966. Haul seine and trap net development and improvement based on related biological fishery research in Tennessee reservoirs. Job Completion Report 4-5-R-1 for the Tennessee Game and Fish Commission, Nashville.

Holz, D. D. 1969. The ecology of the unchannelized and channelized Missouri River, Nebraska, with emphasis on the life history of the flathead catfish. Master's thesis. University of Missouri, Columbia.

Jenkins, R. M., and J. C. Finnell. 1957. The fishery resources of the Verdigris River in Oklahoma. Oklahoma Fishery Research Laboratory, Report 59, Norman.

Kwak, T. J., W. E. Pine, D. S. Waters, J. A. Rice, J. E. Hightower, and R. L. Noble. 2004. Population dynamics and ecology of introduced flathead catfish: phase 1 final report. North Carolina Wildlife Resources Commission, Federal Aid in Sport Fish Restoration Project F-68, Study Number 1, Final Report, Raleigh.

Layher, W. G., and R. J. Boles. 1979. Growth of Pylodictis olivaris (Rafinesque) in a Kansas reservoir. Transactions of the Kansas Academy of Sciences 82:36-48.

Layher, W. G., and R. J. Boles. 1980. Food habits of the flathead catfish, Pylodictis olivaris (Rafinesque), in relation to length and season in a large Kansas reservoir. Transactions of the Kansas Academy of Sciences 83:200-214.

Maceina, M. J. 1988. Simple grinding procedure to section otoliths. North American Journal of Fisheries Management 8:141-143.

Mallin, M. A. 2000. Impacts of industrial animal production on rivers and estuaries. American Scientist 88:26-37.

Mayhew, J. K. 1969. Age and growth of flathead catfish in the
Des Moines River, Iowa. Transactions of the American Fisheries Society 98:118-120.

Mayo, R. M., and H. L. Schramm, Jr. 1999. Growth of flathead catfish in the lower Mississippi River. Pages 121-124 in E. R. Irwin, W. A. Hubert, C. F. Rabeni, H. L. Schramm, Jr., and T. Coon, editors. Catfish 2000: proceedings of the international ictalurid symposium. American Fisheries Society, Symposium 24, Bethesda, Maryland.

McCoy, H. A. 1953. The rate of growth of flathead catfish in twenty-one Oklahoma lakes. Proceedings of the Oklahoma Academy of Science 34:47-52.

Media Cybernetics. 2002. Image-Pro Plus, version 4.5 for Windows, reference guide. Media Cybernetics, Silver Spring, Maryland.

Minckley, W. L., and J. E. Deacon. 1959. Biology of the flathead catfish in Kansas. Transactions of the American Fisheries Society 88:344-355.

Nash, M. K. 1999. Age and growth of flathead catfish and channel catfish in the Tallapoosa River, Alabama, and the Ocmulgee River, Georgia. Master's thesis. Auburn University, Auburn, Alabama.

Nash, M. K., and E. R. Irwin. 1999. Use of otoliths versus pectoral spines for aging adult flathead catfish. Pages 309-316 in E. R. Irwin, W. A. Hubert, C. F. Rabeni, H. L. Schramm, Jr., and T. Coon, editors. Catfish 2000: proceedings of the international ictalurid symposium. American Fisheries Society, Symposium 24, Bethesda, Maryland.

Pate, M. W. 1980. Age and growth of flathead catfish, Pylodictis olivaris, in the Rio Grande River, Texas. Annual Proceedings of the Texas Chapter, American Fisheries Society 3:92-102.

Pine, W. E. III. 2003. Population ecology of introduced flathead catfish. Doctoral dissertation. North Carolina State University, Raleigh.

Pine, W. E. III, T. J. Kwak, D. S. Waters, and J. R. Rice. 2005. Diet selectivity of introduced flathead catfish in coastal rivers. Transactions of the American Fisheries Society 134:901-909.

Pisano, M. S., M. J. Inansci, and W. L. Minckley. 1983. Age and growth and length-weight relationship for flathead catfish, Pylodictis olivaris, from Coachella Canal, southeastern California. California Fish and Game 69:124-128.

Purkett, C. A. Jr. 1958. Growth of the fishes in Salt River, Missouri. Transactions of the American Fisheries Society 87:116-131

Quinn, S. P. 1989. Flathead catfish abundance and growth in the Flint River, Georgia. Proceedings of the Annual Conference Southeastern Association of Fish and Wildlife Agencies 42(1988):141-148.

Quinn, S. P. 1991. Evaluation of a length categorization system for flathead catfish. Proceedings of the Annual Conference Southeastern Association of Fish and Wildlife Agencies 43(1989):146-152.

Quinn, S. P. 1993. Description of a multiuse fishery for flathead catfish. North American Journal of Fisheries Management 13:594-599.

Ratkowsky, D. A. 1983. Nonlinear regression modeling: a unified practical approach. Marcel Dekker, New York.

Ricker, W. E. 1975. Computation and interpretation of 
biological statistics of fish populations. Fisheries Research Board of Canada Bulletin 191.

Robinson, J. W. 1997. The development of a qualitative system to evaluate populations of channel catfish and flathead catfish in the Missouri and Mississippi rivers. Missouri Department of Conservation, Final Report, Project F-1-R-46, Columbia.

SAS Institute. 1994. SAS/STAT user's guide, release 6.10. SAS Institute, Cary, North Carolina.

Seber, G. A. F. 1982. The estimation of animal abundance and related parameters, 2nd edition. Charles Griffin, London.

Stauffer, K. W., R. C. Binder, B. C. Chapman, and B. D. Koenen. 1996. Population characteristics and sampling methods of flathead catfish Pylodictis olivaris in the Minnesota River. Minnesota Department of Natural Resources, Final Report, Project F-29-R(P)-15, St. Paul.

Summerfelt, R. C., L. Hart, and P. R. Turner. 1972. Flathead catfish movements. Oklahoma Department of Wildlife
Conservation, Completion Report, Project 4-60-R, Oklahoma City.

Turner, P. R. 1982. Procedures for age determination and growth rate calculations of flathead catfish. Proceedings of the Annual Conference Southeastern Association of Fish and Wildlife Agencies 34(1980):253-262.

Winkelman, D. L. 2002. Factors influencing fish populations in Oklahoma waters: evaluation of the flathead catfish population and fishery on Lake Carl Blackwell, OK, with emphasis on the effects of noodling. Oklahoma Department of Wildlife Conservation, Final Report, Project F-41-R, number 23, Oklahoma City.

Young, K. L., and P. C. Marsh. 1990. Age and growth of flathead catfish in four southwestern rivers. California Fish and Game 76:224-233.

Zar, J. H. 1996. Biostatistical analysis, 3rd edition. Prentice Hall, Upper Saddle River, New Jersey. 